\title{
Gross Osteology and digital radiography of the common Capybara (Hydrochoerus hydrochaeris), Carl Linnaeus, 1766 for scientific and clinical application
}

\section{Osteologia bruta e radiografia digital da capivara comum (Hydrochoerus hydrochaeris), Carl Linnaeus, 1766 para aplicação científica e clínica}

\author{
Derek Andrew Rosenfield ${ }^{1}$ (D); Nicole Fidalgo Paretsis²; Priscila Rocha Yanai²; Cristiane Schilbach Pizzutto ${ }^{1}$
}

\footnotetext{
${ }^{1}$ Universidade de São Paulo, Faculdade de Medicina Veterinária e Zootecnia, Departamento de Reprodução Animal, São Paulo - SP, Brazil

${ }^{2}$ Universidade de São Paulo, Faculdade de Medicina Veterinária e Zootecnia, Departamento de Cirurgia, São Paulo - SP, Brazil
}

\begin{abstract}
Being able to study anatomical structures of wildlife species for science and clinical practice is of great importance. We aimed to describe the normal gross osteology of the common adult capybara Hydrochoerus hydrochaeris (Linnaeus, 1766), using macerated bone specimens and high-resolution digital radiography. The complete axial and appendicular skeleton was further compared with previously reported anatomical findings. For this purpose, we used three adult capybara cadavers (two females and one male), with a mean bodyweight of $\pm 50 \mathrm{~kg}$. Some H. hydrochaeris-specific morphological characteristics, especially in the skull region, show evidence of adaptation to aquatic life, such as an elongated head shape, with eyes, ears, and nose, located dorsally, to stay above water. Additionally, the entire bone structure demonstrates the size and weight support of the largest rodent and its adaptation with respect to foraging and locomotion behaviors. As a semi-aquatic herbivore, classified as cursorial (having limbs adapted for running), the authors believe it should be reclassified as cursorial-swimming/diving. Moreover, we argue to consider a differentiation between $H$. hydrochaeris silvestris to $H$. hydrochaeris synanthrope, due to substantial weight variation, in some cases $>100 \%$. This inevitably has an impact on the development of bone structure, thus influencing habitual adaptation, and consequently, its clinical implications and animal handling. Radiography exams helped in the identification of bone structures, which otherwise were not observed in anatomical specimens, such as ossa sesamoidea, including the ossicle lunulae. Likewise, the radiographs were particularly helpful in overall better comprehension of the intubation and catheterization procedures. We believe this work can contribute as a reference to anatomical studies for students and professionals acting in clinic, surgery, and research.
\end{abstract}

Keywords: Digital X-ray. Anatomy. Hydrochoerus hydrochaeris. Rodentia. Caviidae.

\section{RESUMO}

Ser capaz de estudar estruturas anatômicas dos animais da fauna para fins científicos e prática clínica é de grande importância. Objetivamos descrever a osteologia geral normal de capivaras adultas Hydrochoerus hydrochaeris (Linnaeus, 1766), usando amostras de ossos macerados e radiologia digital de alta resolução. O esqueleto axial e apendicular foi posteriormente comparado a achados anatômicos reportados anteriormente. Para esse fim, nós utilizamos de três cadáveres de capivaras adultas (duas fêmeas e um macho) com peso médio de cerca de $50 \mathrm{~kg}$. cada. Algumas características morfológicas de cavidade específicas, especialmente na região do crânio, evidenciam a adaptação à vida aquática, como o formato alongado da cabeça, com olhos, orelhas e nariz localizados dorsalmente, para permanência sobre a água. O completo desenvolvimento morfológico ósseo é evidência de tamanho e suporte de peso do maior roedor, assim como de seus hábitos de alimentação e locomoção, sendo um herbívoro semiaquático, classificado como cursório (tendo membros adaptados à corrida), caso em que os autores acreditam deveria ser reclassificado como cursorial-natação/ mergulho. Além disso, argumentamos que deve ser considerada uma diferenciação entre $H$. hydrochaeris silvestris e H. hydrochaeris sinantropo, devido ao fato da variação substancial de peso, em alguns casos $>100 \%$, inevitavelmente terá um impacto no desenvolvimento da estrutura óssea, influenciando, assim, a adaptação habitual e, consequentemente, suas implicações clínicas e manejo animal. A radiografia auxiliou na correlação e identificação de estruturas ósseas que não observadas em espécimes anatômicos, como o osso sesamóide, incluindo o ossículo lunar. Ademais, as radiografias 
foram particularmente úteis para uma melhor compreensão geral de procedimentos de intubação e cateterização. Acreditamos que este trabalho possa contribuir como referência de estudos anatômicos para estudantes e profissionais atuantes em clínica, cirurgia e pesquisa.

Palavras-chave: Radiografia digital. Anatomia. Hydrochoerus hydrochaeris. Rodentia. Caviidae.

Correspondence to:

Derek Andrew Rosenfield

Universidade de São Paulo, Faculdade de Medicina Veterinária

e Zootecnia, Departamento de Reprodução Animal

Av. Prof. Dr. Orlando Marques de Paiva, 87, Cidade

Universitária

CEP: 05508-270, São Paulo - SP, Brazil

e-mail:dro@alumni.usp.br

Received: July 12, 2020

Approved: September 23, 2020
How to cite: Rosenfield DA, Paretsis NF, Yanai PR, Pizzutto CS. Gross Osteology and digital radiography of the common Capybara (Hydrochoerus hydrochaeris), Carl Linnaeus, 1766 for scientific and clinical application. Braz J Vet Res Anim Sci. 2020;57(4):e172323. https://doi. org/10.11606/issn.1678-4456.bjvras.2020.172323

\section{Introduction}

Capybaras are the world's largest rodent and native throughout South America. As semi-aquatic herbivores, they can be seen either in or close to water, hence their scientific name, Hydrochoerus hydrochaeris. The name is derived from the Greek hydro, meaning "water," and choíros, meaning "pig"- a misnomer, given pigs (Sus scrofa) do not belong to the Rodentia order (Moreira et al., 2013). Capybaras belong to the Caviidae family, which includes guinea pigs (Cavia porcellus), also native to South America. The only other member of the Hydrochoerus genus is $H$. isthmius, the lesser capybara, native to some Caribbean islands (Herrera, 2013; Moreira et al., 2013). In the areas of their natural habitat, the average adult weight reaches between 40 and $50 \mathrm{~kg}$. As they become synanthropic wildlife (invading agricultural and urban areas with abundant high-caloric food sources), adults may weigh over $100 \mathrm{~kg}$ (Abreu Bovo, 2016; Rosenfield et al., 2019a). To control their super populations and combat the associated spread of zoonotic disease, as well as other human-wildlife conflicts, capybara has recently become the subject of several research projects (Luz et al., 2019; Passos Nunes et al., 2019; Rosenfield \& Pizzutto, 2019; Rosenfield et al., 2019a, 2019b; Yanai \& Cortopassi, 2020), or require medical attention due to injuries suffered during common human-capybara conflicts, as well as clinical care in zoos and parks around the world, and even as pets. Having a solid understanding of the anatomy of the wildlife species, particularly when working with them in the field, aids in the often-multidisciplinary research activities, including capture strategies by physical and chemical restraint, physical examination, and planning and performing clinical or surgical procedures. The capybara's specific anatomy includes the odd-shaped head and barrel-like body, adapted for life in and around the water. The body shape allows perfect hydrodynamic diving and swimming, supported by inter-digital netting, while the head shape allows maintaining the eyes, ears, and nose above the water level. Perhaps the most prominent feature of these herbivores is their enormous and sharp incisors. They provide an ideal tool to cut vegetation and grasses to the root, as well as for defense. The incisors and molars grow continuously, which makes their use as an estimator of age much less feasible (Ojasti, 1973). Besides obtaining radiographic images, additional objectives were to practice orotracheal intubation, which is rather challenging, compared to other species (Girotto, 2018), and urethral catheterization, for future pharmaceutical induced semen collection techniques (Araujo et al., 2020; Rosenfield et al., 2019a). Although several publications have partially described the anatomic and radiographic structures of H. hydrochaeris (Araújo et al., 2012; Bode et al., 2016a, 2016b; Brombini et al., 2018; Hirota et al., 2018; Kihara, 2017; Schimming et al., 2015; Silva, 2019), this is the first reference on the complete radiographic skeletal anatomy, supported by bone specimens, intended as a reference for scientific studies and clinical-surgical applications.

\section{Materials and Methods}

This study, part of a larger project on Capybara Population Control, was approved by the Animal Use and Ethics Committee FMVZ/USP (n. 9553260816) and by the Ministry of the Environment Chico Mendes Institute for Biodiversity Conservation, Biodiversity Information, and Authorization System - SISBIO (n. 54634-4).

\section{Specimens}

Three adult capybara cadavers (two females, one male) were used, with a mean bodyweight of $\pm 50 \mathrm{~kg}$. As per (Moreira et al., 2013), animals with a mean body mass of 
$>40 \mathrm{~kg}$ are considered adults. The specimens used came from the Department of Veterinary Clinic and Surgery, Faculty of Veterinary Medicine and Animal Science, University of São Paulo, delivered post-mortem and kept in a temperature-controlled storage unit until routine necropsy. Before the radiographic study, the animals were thawed to ambient temperature. Before the radiographic presentation, some distinct anatomical characteristics of the capybaras were presented. All bone specimens were obtained from the Museum of Natural History, Municipal Zoo, Guarulhos, São Paulo.

\section{Nomenclature, labeling}

Anatomic structures were color-labeled using gross anatomical nomenclature following Nomina Anatomica Veterinaria, Sixth Edition, International Committee on Veterinary Gross Anatomical Nomenclature (2017).

The anatomical descriptions follow the same sequence as listed in the NAV 2017 and are organized into:

Skeleton Axis: Cranium; Columna vertebrae: Vertebrae cervicales; Vertebrae thoracicae; Vertebrae thoracicae; Vertebrae lumbales; Vertebrae sacrum; Vertebrae caudales.

Skeleton thoracis: Costae - sternum.

Skeleton Appendiculare: Ossa membri thoracici: Cingulum membri thoracici; Skeleton antibrachii - brachii; Skeleton manus; Osso membri pelvini: Cingulum membri pelvini; Skeleton femoris; Skeleton cruris; Skeleton pedis.

\section{Images}

In general, the images follow the sequence listed in the NAV 2017. However, where applicable, figure numbers might be out of sequence in the text due to combined anatomy imaging (Scheme 1).

For ease of identification, the nomenclature has been placed directly next to anatomical structures.

\section{Radiography}

For radiographic imagery, the cadavers were positioned in dorsal or lateral recumbency for craniocaudal, ventrodorsal,

\section{Label Color Indicator}

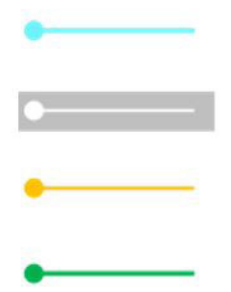

Light blue lines indicate bone structures

White Lines indicate space or orifices

Yellow lines indicate region or soft tissue

Green lines indicate non-organic structures

Scheme 1 - Label - Nomenclature. dorsoplantar, or mediolateral projection, respectively, using the digital radiographic equipment (Mix X Ray', Northbrook, IL, USA, Sound Elkin ${ }^{\circ}$, Carlsbad, CA, USA, Software E-film ${ }^{\mathrm{Tm}}$, 3.3 Workstation). A focus-film distance of $100 \mathrm{~cm}$ and exposure of $70 \mathrm{kV}, 6.4 \mathrm{mAs}$ was employed as a standard-setting.

\section{Endotracheal tube placement}

During intubation training, a laryngoscope with extended blade and 7.0 metal-reinforced tracheal tube, cuffed, Murphy eye, Mallinckrodt, IRL, was used.

\section{Urinary catheterization}

Urinary catheterization training, a 6.0 urethral tube, CPL Medical, BR was used, and subsequently, a barium sulfate contrast solution was injected for urethrography.

\section{Results - Osteology (As Presented and Identified, Either Macroscopically or by Radiography)}

Capybara Skeleton - Overview Gross Osteology (Figure 1)

Cranium: Os occipitale (1), os interparietale (n/o), os sphenoidale (1), os pterygideum (1), os temporale (2), os parietale (1), os frontale (2), os vomer (1), os nasale (2), os lacrimale (2), maxillia (1), os incisivum (2), os palatinum (2), os zygomaticum (2), mandibulae (1).

Columna vertebralis: Vertebrae cervicales (7), thoracicae (13), lumbales (6), sacrales (4), coccygeae (8).

Skeleton thoracis: Costae (26), sternebrae (5).

Skeleton appendicular

Membri thoracici

Scapula (2). Brachii: the humerus (2), ulna (2). Antibrachii: Radius (2), Ulna (2). Skeleton manus: Ossa carpi (14), ossa metacarpalia (10). Ossa sesamoideum metacarpale, Ossa digitorum manus: Phalanx proximalis/media/distalis (12). Ossa sesamoidea proximalia.

Membri pelvini: Os coxae: Os ilium (2), os ischii (2), os pubis (2). Skeleton femoris: Osfemoris (2). Ossa sesamoidea m. gastrocnemii (2), os sesamoideum m poplitei (2). Patella (2). Sesamoid ossicle lunulae (4). Os Skeleton cruris: Os tibia (2), os fibula (2). Skeleton pedis: Ossa tarsi (2), os talus (2), os calcaneus (2), os tarsale (14), ossa metatarsalia (8), os sesamoideum metatarsale (12). Ossa digitorum pedis: Phalanx proximalis (2), medialis (2), dorsalis (2).

Partes Genitales Masculina

Os penis, baculum, or penile bone (1).

Skeleton Axiale

Cranium I \& II (Figure 2a, b) 


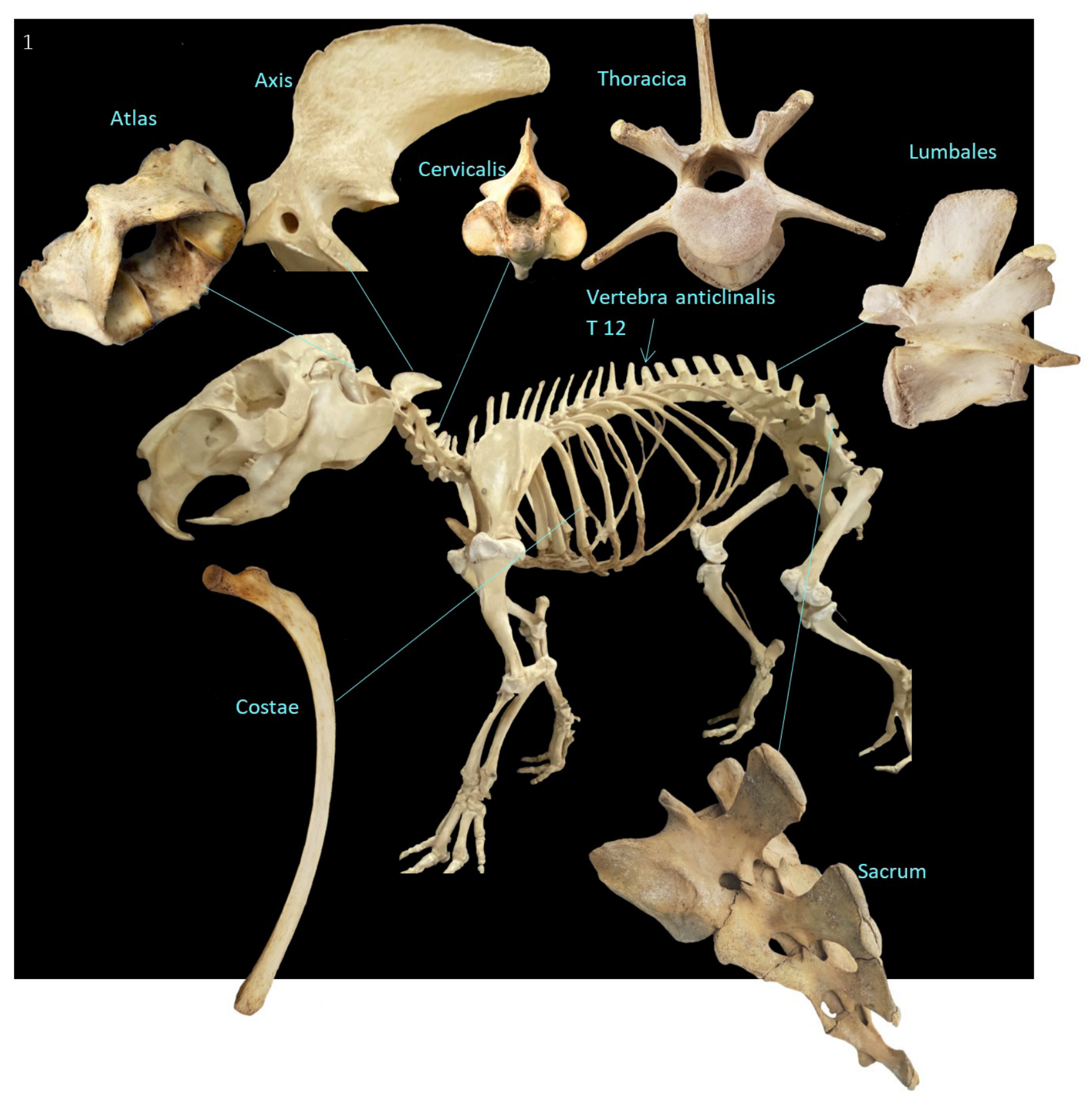

Figure 1 - Gross osteology, oblique/lateral view of an adult capybara skeleton with magnified vertebrae and costae. 2019.

The barrel-shaped skull is rostrocaudally elongated with a prominent processus zygomaticus and a narrow-ending nasal portion. The cranium, comprised of a cranial and a facial section, consists of 34 facial bones, divided into paired and unpaired bones, including ossicula auditus. The pars nasalis, situated rostral to the os frontale, forms the greater part of the nasal cavity roof and concha nasalis dorsalis, housing the turbinalia and is articulated, at its posterior extremity, to the os frontale and os lacrimale, while at its anterior extremity, to the os incisivum. The os frontale, forming the forehead, is part of the cranial and nasal cavity, articulated to the os lacrimale, representing the dorsal aspect of the orbita formation, and to the os parietale at the caudal end. The os lacrimale form the cranial-basal portion of the orbita articulated superiorly with the os frontale, os lacrimale, and inferiorly with the os zygomaticum, in addition to the corpus maxillae. The os zygomaticum, and processus zygomaticus of the corpus maxillae, situated ventrolateral to the os lacrimale, are prominent. Part of the lateral aspect of the orbita articulates to the corpus maxillae. The concave-shaped corpus maxillae, parallel to diastema region, between the os incisivum and premolar, whose cranial extension forms the fissura infraorbitale, articulating with the os zygomaticus, lacrimale, frontale, and nasalis. At its ventral aspect, providing the alveoli for the four molares, and forming the bony base of the palatum durum and the wall of the oral and nasal cavity. The os incisivum located dorsally and rostrally to the corpus maxillae, rather elongated and narrow-shaped 


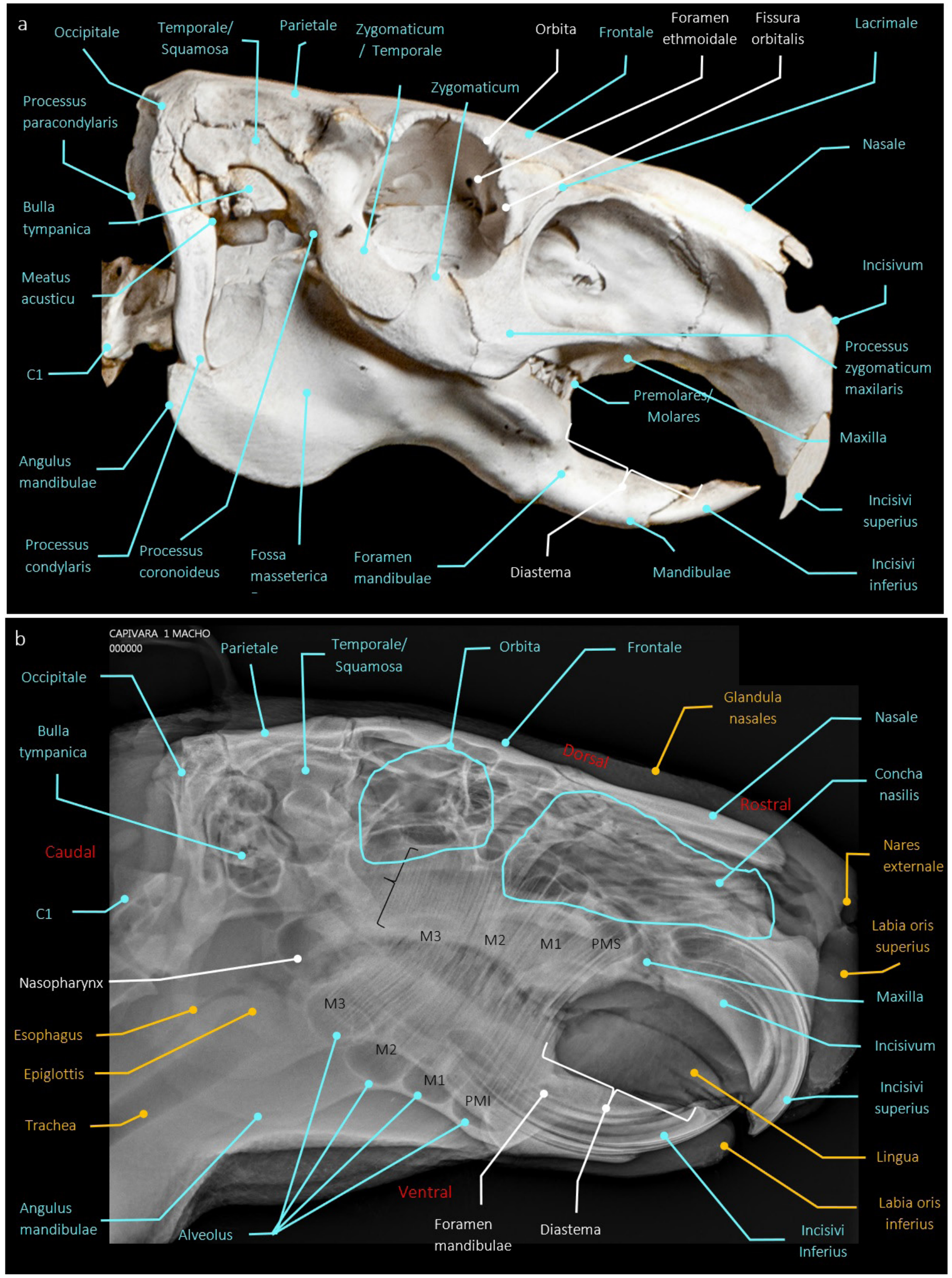

Figure 2 - (a) Lateral view of the cranium; (b) Laterolateral radiographic projection of the cranium. PM: pre-molar; PMI/PMS: Pre-molar Inferior e Pre-molar Superior; M1-3: molar; Black bracket: Vertical lines of enamel laminae; C1: 1st vertebrae cervicales. 
on its extremity, houses the massive incisors, articulated dorsally with the os nasalis and caudally with the corpus maxillae. The corpus mandibula houses the inferior incisive teeth at the rostral extremity and the molars at the caudal part, with an enlarged diastema (interalveolar margin) in between. The foramen mentale was visible inferior of the incisive tooth, and identifiable at the radiograph. The os palatinum, at the ventral aspect of the cranium, comprises the roof of the oral cavity, between the corpus maxillae and the os sphenoidale, in a distinct triangular shape, articulated rostrally to the corpus maxillae and caudally with the limits of the bony palatinum. The os vomer appeared absent in capybaras. The orbita eye margin presented a large and spherical shape, found in a lateralized position, made up of the os frontale, temporale, lacrimale, and sphenoidalis, and the processus zygomaticus.

\section{Cranium I}

\section{Dental (Figure 2a, b, 3a, b)}

Most noticeable are the enormous dentes incisivi, where the exposed portion of each tooth may reach a length of $7 \mathrm{~cm}$ and a width of $1 \mathrm{~cm}$. The cavum dentis shows a wide diastema between the dentes incisivi and the dentes premolares. The maxillary/mandible dental formula is:

$$
I \frac{1}{1}, C \frac{0}{0}, P M \frac{1}{1}, M \frac{3}{3}=\frac{1013}{1013} * 2=20
$$

$\mathrm{I}=$ dentes incisor, 0 dentes canini $\mathrm{PM}=$ dentes premolares, $\mathrm{M}=$ dentes molares, whereby the $3 \mathrm{rd}$ dente molares superior is twice the size of the $3 \mathrm{rd}$ dente molares inferior (covering the width of the 2 nd and $3 \mathrm{rd}$ dentes molares inferiores), with a relative wide diastema between the dentes incisivi and the dentes premolares. The dentes premolares and molares show vertical lines denoted as laminas enamelum, a protective layer around the dentinum, which in turn, surrounds the pulpa dentis.

\section{Cranium II}

\section{Columna vertebralis}

\section{Vertebrae cervicales (C1-C7) (Figure 4a, b)}

The capybara has seven vertebrae cervicales, gradually decreasing size in the caudal direction. All vertebrae present a processus transversus and processus spinosus. The atlas (C1) articulated cranially with the cranium and caudally with the axis (C2) which showed a well-developed processus spinosus, projecting caudally. The radiograph provides a clear view of the vertebrate canal through which the medulla spinalis passes.

\section{Columna vertebrae}

\section{Vertebrae cervicallis}

Vertebrae thoracicae (T1-T13) (Figure 5a, b)

Contrary to the vertebrae cervicales, the vertebrae thoracicae increase in size in the caudal direction. We observed T12 with the characteristics of a vertebrae anticlinalis.

Vertebrae thoracicae; Costae; Sternum

Vertebrae lumbales (L1-L6) (Figure 6a, b)

The seven lumbar vertebrae bodies do not show a distinct size variation, whereas their processus spinosus and processus transversus show a prominent development.

Vertebrae sacrales (S1-S4) (Figure 6a, b)

Os sacrum is a large, triangular bone, fused by 4 vertebrae sacrales, located at the base of the Columna vertebralis, post vertebrae lumbales.

Vertebrae caudales/coccygae (I-VIII) (Figure 6a, b)

The vertebrae caudales $\mathrm{I}-\mathrm{V}$ show similar characteristics of prior described vertebrae, with a processus spinosus but without processus transversus. Vertebrae caudales VI-VIII are without processus spinosus, presenting a cylindrical corpus vertebra.

\section{Vertebrae lumbales/sacrales}

\section{Skeleton thoracis}

\section{Costae (Figure 7a, b)}

The cavum thoracis (rib cage) is made up of 13 pairs of os costale, with the caput costae, at their dorsal end, joining with the vertebrae thoracicae, right at the processus transversus. On its ventral side, the ribs connect to the sternum, which presents 5 sternebrae, and a large processus xiphoideus caudally, the manubrium sterni cranially.

\section{Skeleton appendicular}

\section{Ossa membri thoracici}

\section{Cingulum membri thoracici}

\section{Scapula/Clavicula (Figure 7a,b)}

At the scapula, we noticed prominent structures at the spina scapulae extension, processus hamatus, and processus suprahamatus, projecting toward the shoulder joint. The glenoid cavity and supraglenoid tubercle are fairly evident. The clavicula was not observed microscopically, with possible identification radiographically. 

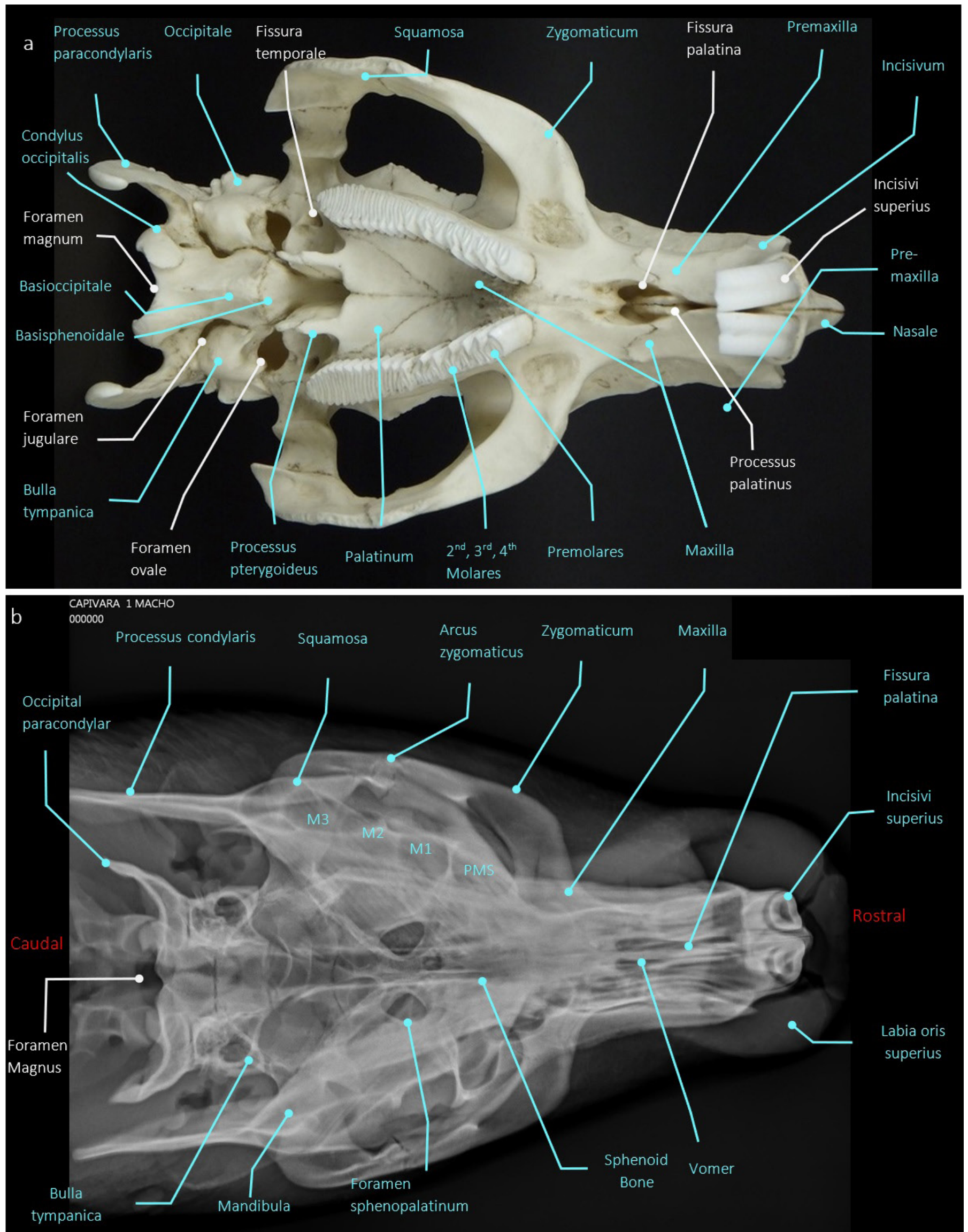

Figure 3 - (a) Ventral view of the cranium; (b) Ventrodorsal radiographic projection of cranium. 

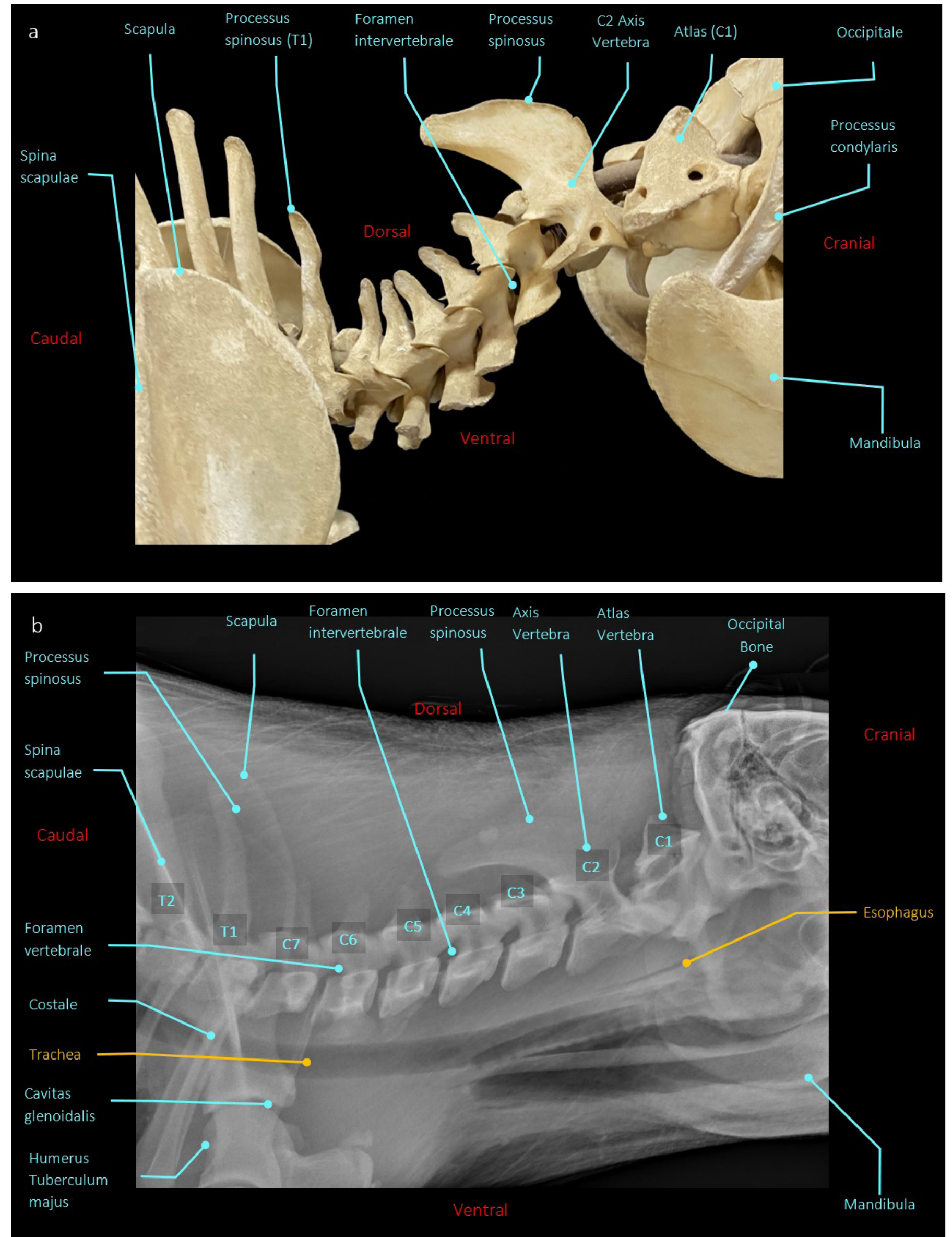

Figure 4 - (a) Lateral view of vertebrae cervicales/thoracicae; T1/T2: First/Second vertebrae thoracicae; C1 - C7: (b) Laterolateral radiograph projection of vertebrae cervicales/thoracicae. 

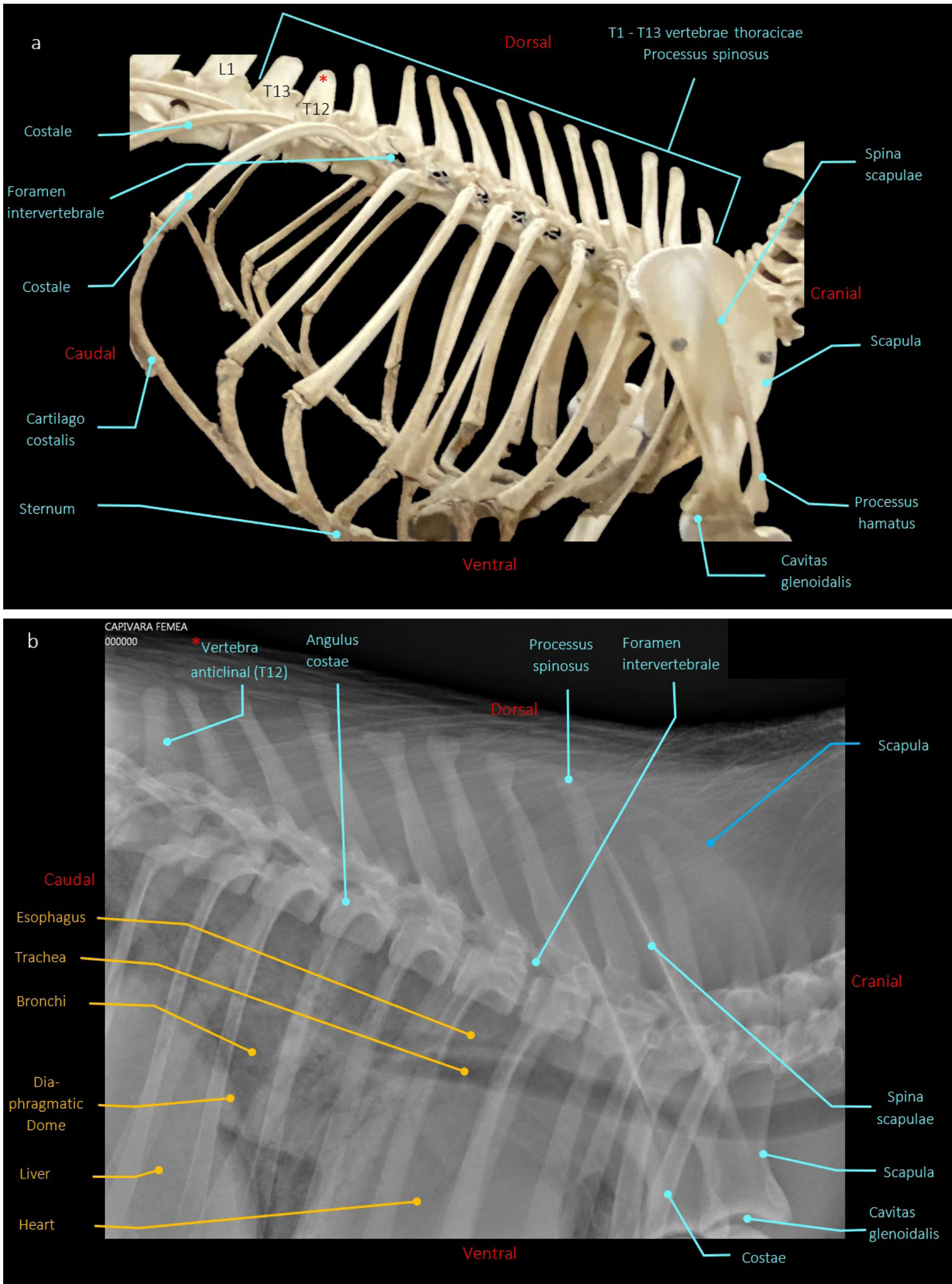

Figure 5 - (a) Lateral view of vertebrae thoracicae, with identification of *anticlinalis vertebra; T12/T13: Twelfth/Thirteenth vertebra thoracicae; L1 First vertebrae lumbales; (b) Laterolateral radiograph projection of Vertebrae thoracicae, with identification of *anticlinalis vertebra. 

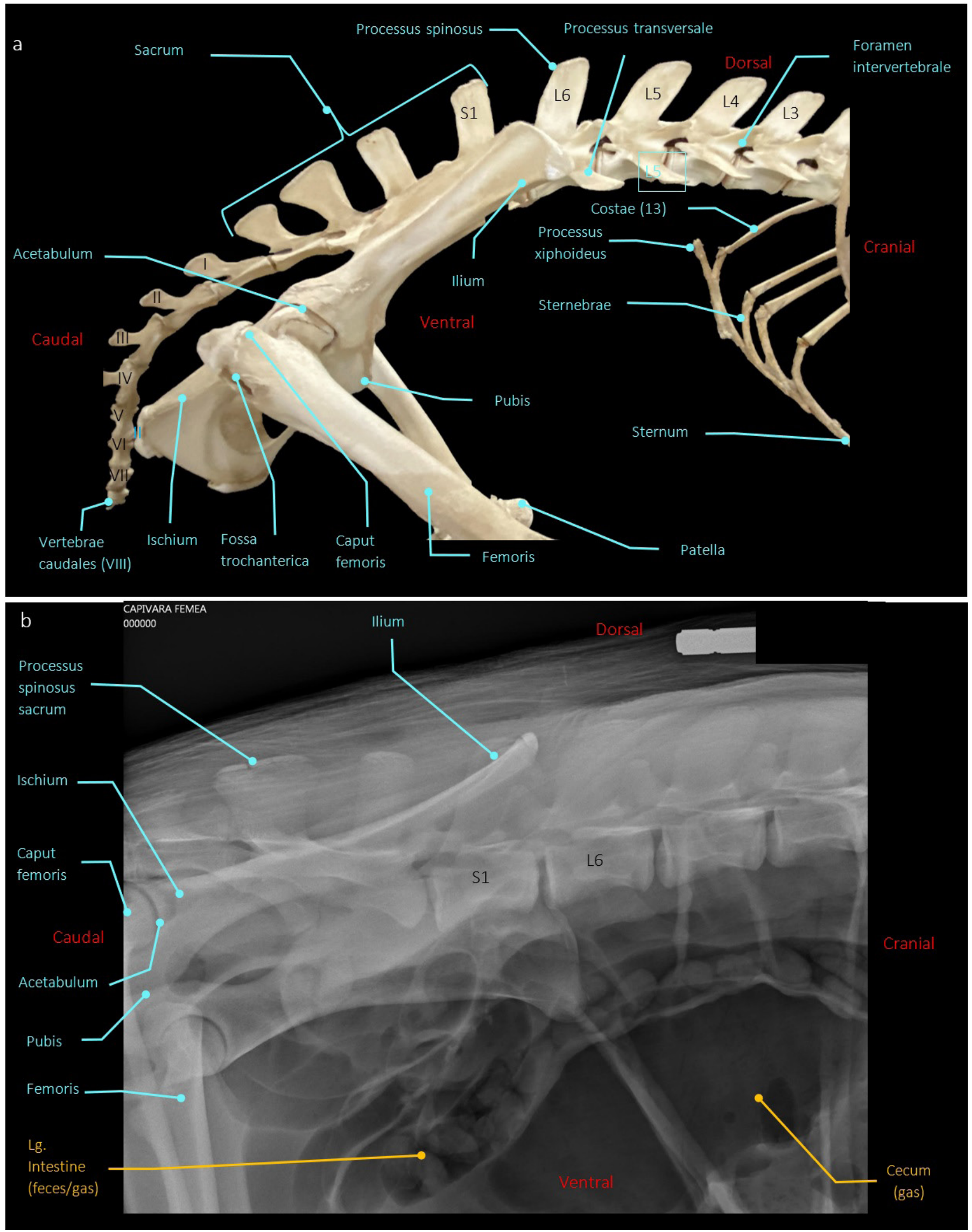

Figure 6 - (a) Lateral view of vertebrae lumbales, vertebrae sacrales, vertebrae caudales; (b) Laterolateral radiographic projection of vertebrae lumbales, vertebrae sacrales, vertebrae caudales. 

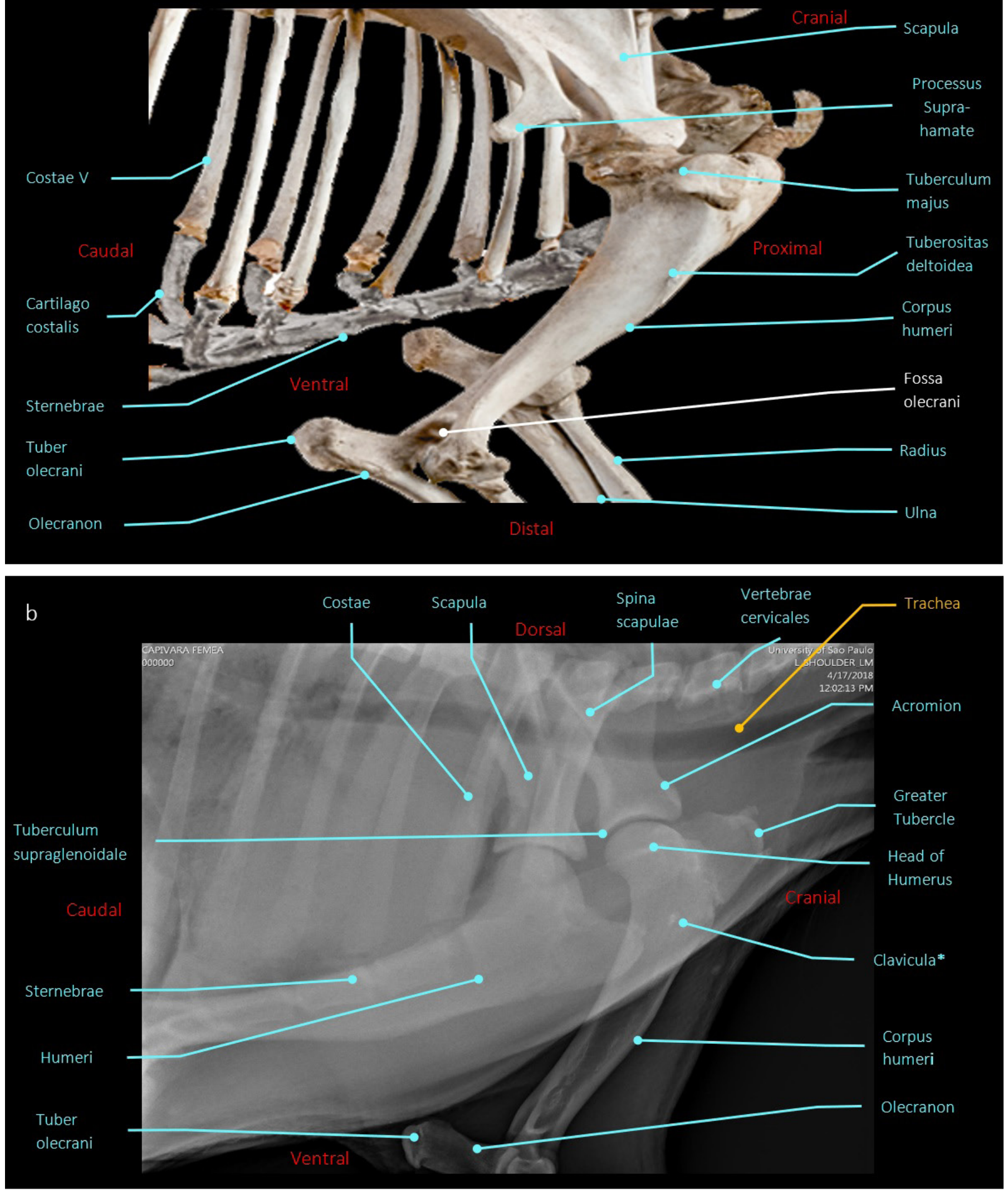

Figure 7 - (a) Lateral view of cingulum membri thoracici; (b) Laterolateral radiographic projection of cingulum membri thoracici. *Possible ID of os clavicula. 


\section{Skeleton appendicular - Ossa membri thoracici - Cingulum membri thoracici}

\section{Skeleton brachii}

Humerus (Figure 7a, b, and Figure 8a, b)

The humerus, with its wide proximal end and large caput humeri, a well-developed tuberculum majus, and evident tuberositas deltoidea greater evident at the distally of the proximal third. On its distal end, separating the lateral located capitulo humeri, form the medially located trochlea humeri by a wide and communicating fossa olecrani, allowing for the accommodation of the processus anconeus of the ulna.

Skeleton antibrachii

Ulna (Figure 8a, b)

The $u \ln a$, a slightly curved log bone, is easily identified by its pronounced olecranon on its proximal end, combining the humeroulnar, humeroradial, and the radioulnar articulation.

Radio (Figure 8a, b)

The corpus radii, following the same curvature of the corpus ulnae, at its distal end, together with the ulna, forming the antebrachial articulation with the ossa carpi proximalis.

\section{Skeleton antibrachii - brachii}

\section{Skeleton manus}

Ossa carpi, ossa metacarpalia, ossa digitorum manus (Figure 9a, b)

The ossa carpi proximal are composed of the os carpi intermedium, carpi ulnare, and carpi accessorium. The distal row is made up of os carpi I, II, III, and IV. Although the front limb has five ossa metacarpalia, the ossa digitorum manus (proximalis, medialis, and distalis). Ossa sesamoidea is present at the distal end of all ossa metacarpalia.

\section{Ossa membri pelvini}

\section{Cingulum membri pelvini}

Os coxae, os ilium, os ischii, os pubis (Figure 6a, b, 10a, b)

The os coxae consisting of two symmetrical, elongated pelvic bones, each made up of three fused bones, the os ilium, os ischii, and the os pubis, forming the acetabulum, and the foramen acetabulum. The two corpus ossis pubis fused at the ventral midline by the cranially oriented pubic and caudally oriented ischiatic symphysis. Also, easily identifiable is the sulcus obturatorius, a large oval-shaped opening, bilaterally of the pelvis bones, composed of the os pubis and os ischii.

\section{Ossa membri pelvini - cingulum membri pelvini}

\section{Skeleton femoris}

\section{Skeleton femoris}

\section{Os femoris (Figure 6a, b, 10a, b, 11a, b)}

The large caput ossis femoris articulates with the acetabulum at the most proximal extremity, together with the trochanter major, aligned with the caput ossis femoris, trochanter minor, and fossa trochanterica. The fossa trochanterica, particular to rodents, and in its size in $H$. hydrochaeris, representing a deep, and in our macroscopic observation even a continuous orifice, cranial-caudally, and evident at the lateral projection of the radiograph.

Patella (Figure 6a, b, 10a, b, 11a, b)

The patella (in fact the largest sesamoid bone) at the lateral view, the anterior aspect resembling a firefighter helmet, with its basis patellae projecting dorsal-cranially and its apex patellae pointing in the distal direction. With its wide corpus, facing its dedicated place at the deep fossa intercondylaris of the femoris.

Lunulae (Figure 10b, 11b), ossa sesamoidea

During the radiographic examination, the $H$. hydrochaeris os lunulae were evident at the lateromedial projection, and in craniolateral position. Ossa sesamoidea was not evident at the macroscopic exams.

\section{Skeleton cruris}

Tibia (Figure 11a, b)

At the tibia's proximal end, a condylus medialis and lateralis, and malleolus medialis and lateralis were present, with a well-defined tuberositas tibiae. The proximal end of the tibia is significantly wider than its distal end.

Fibula (Figure 11a, b)

The caput fibulae and its corpus fibulae, a thin elongated bone, articulates with the tibia's proximal lateral condyle, and indirectly at the distal extremity, with a soft tissue. Between the central point of the tibial and fibular diaphysis, a rather large interosseous space is evident.

\section{Skeleton cruris}

\section{Skeleton pedis}

Ossa tarsi (Figure 12a, b)

In capybara, the ossa tarsi are made up of the talus, calcaneus, os tarsi centrale, os tarsi I, II, II, IV. The distal row include the os tarsale I, II, III and os centroquartale. 
a
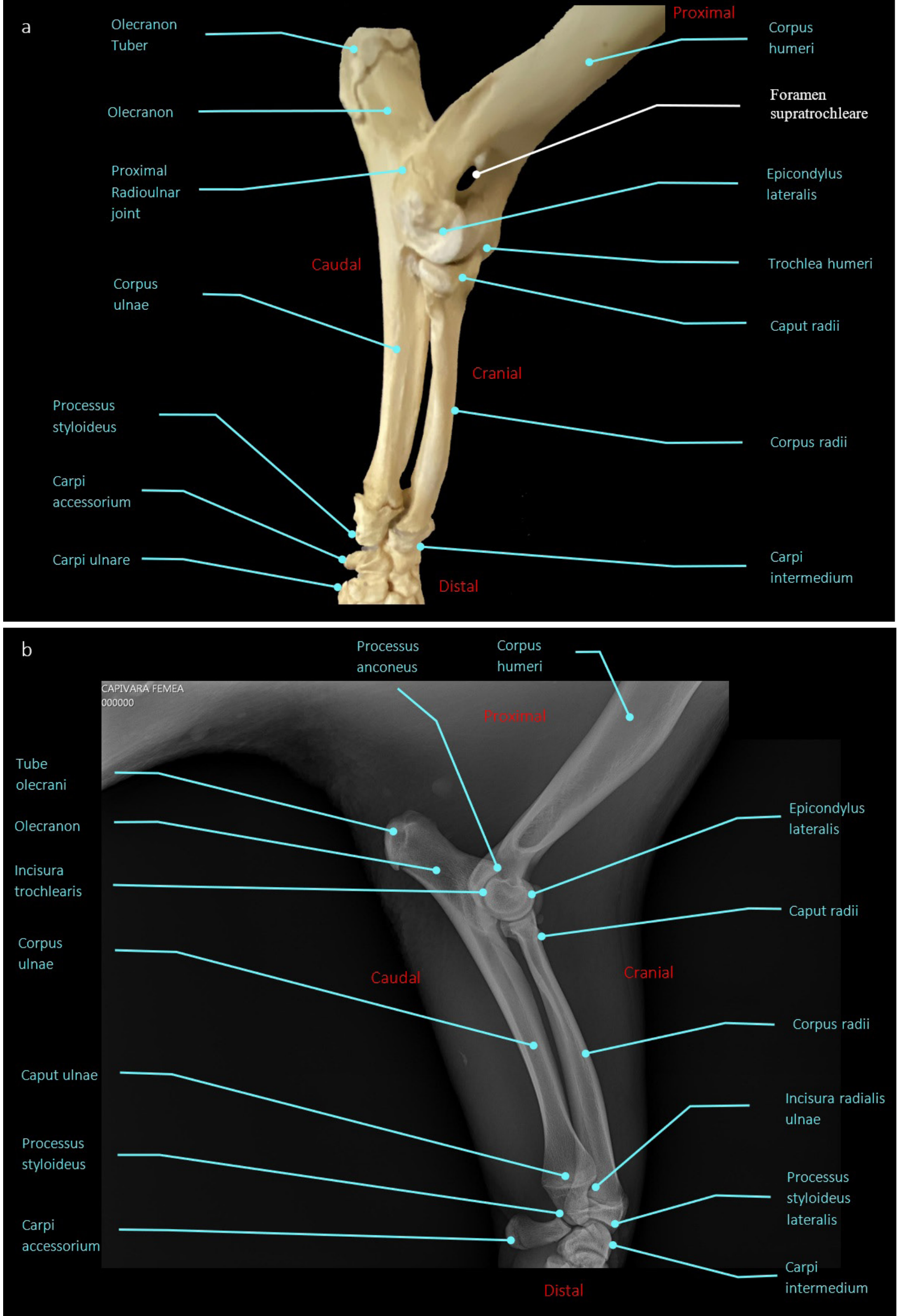

Figure 8 - (a) Lateral view of skeleton antebrachii; (b) Lateromedial radiographic projection skeleton antibrachii. 

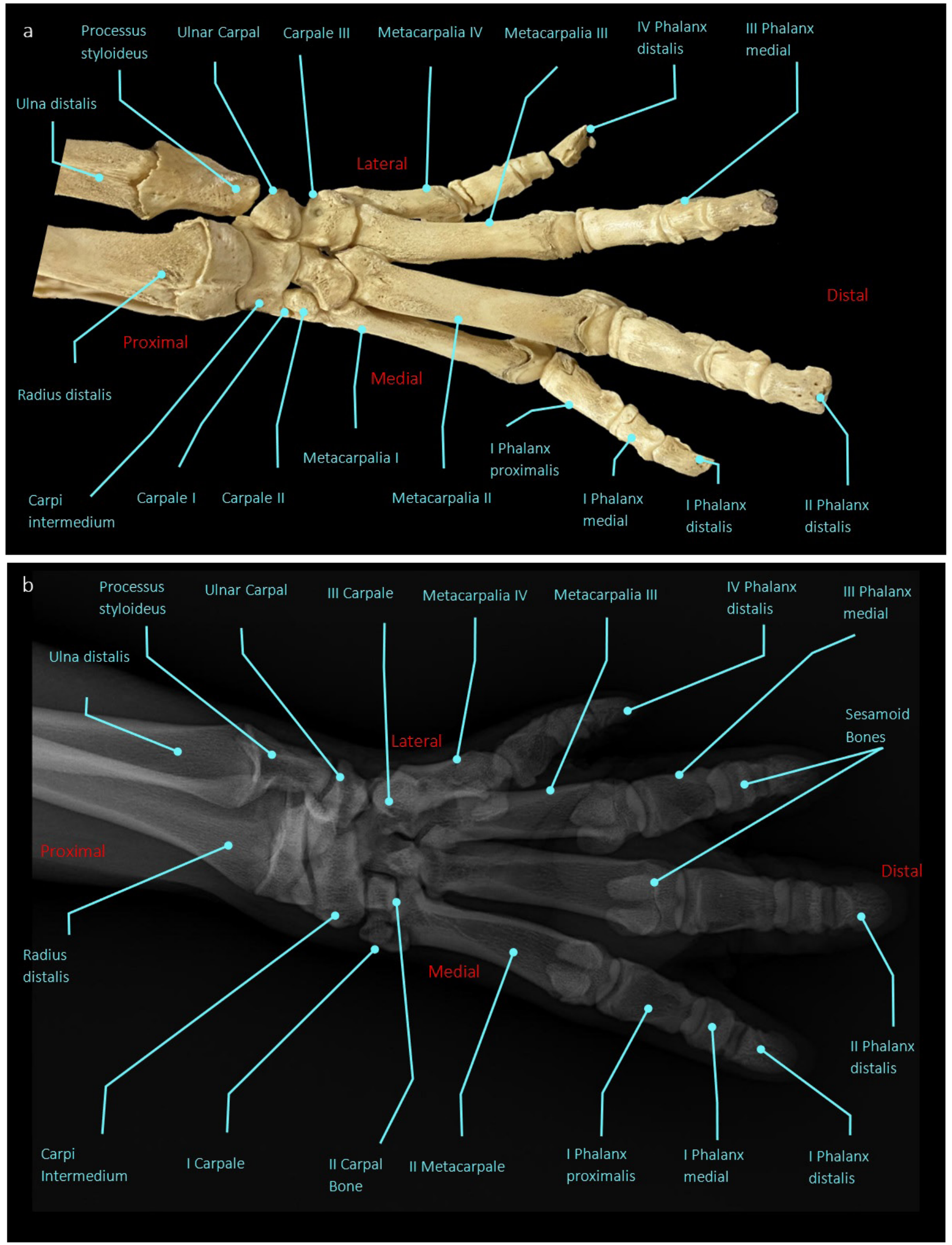

Figure 9 - (a) Dorsal view of skeleton manus; (b) Dorsal radiographic projection of skeleton manus. 

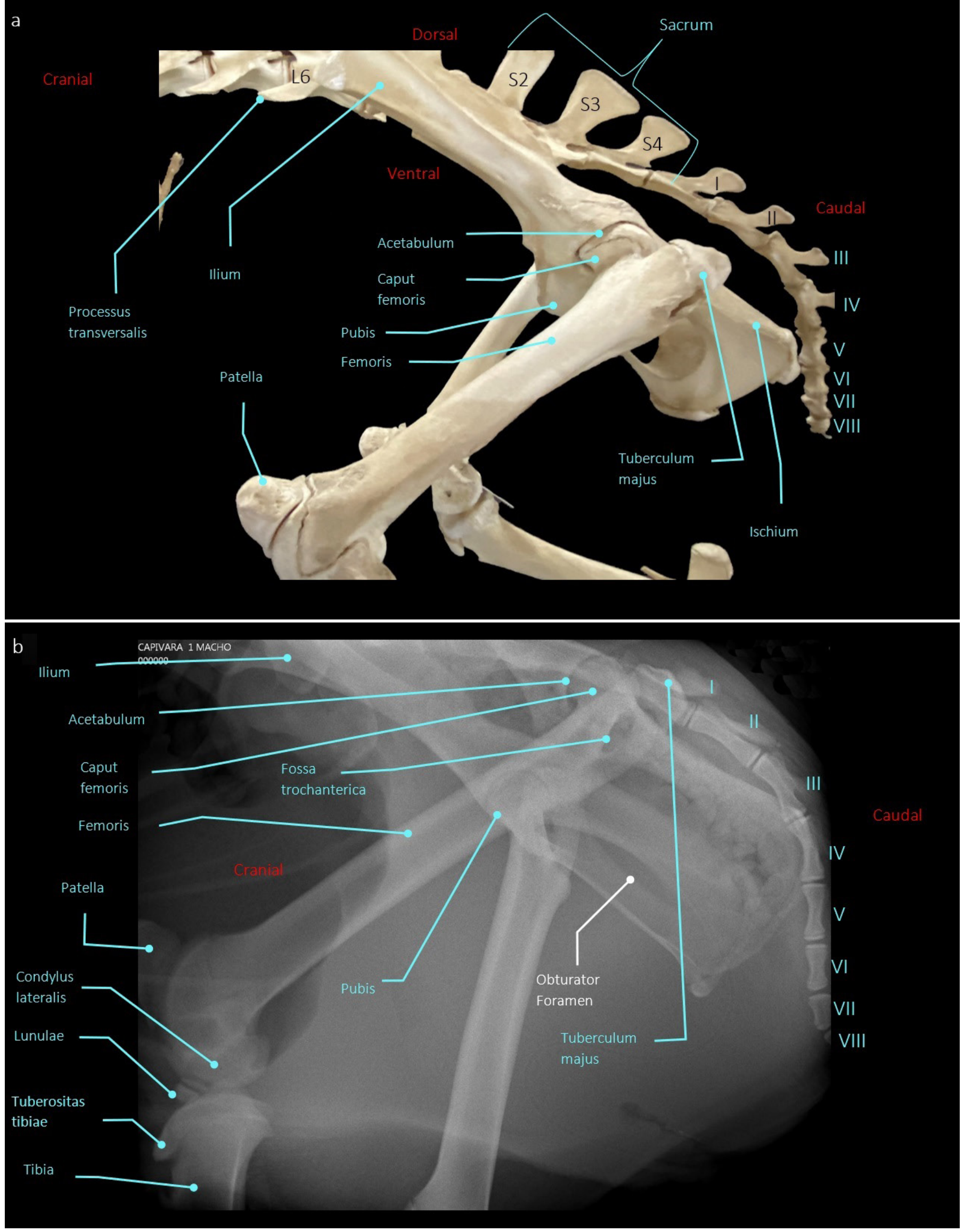

Figure 10 - (a) Lateral view skeleton pelvi; (b) Laterolateral radiographic projection skeleton pelvi. 


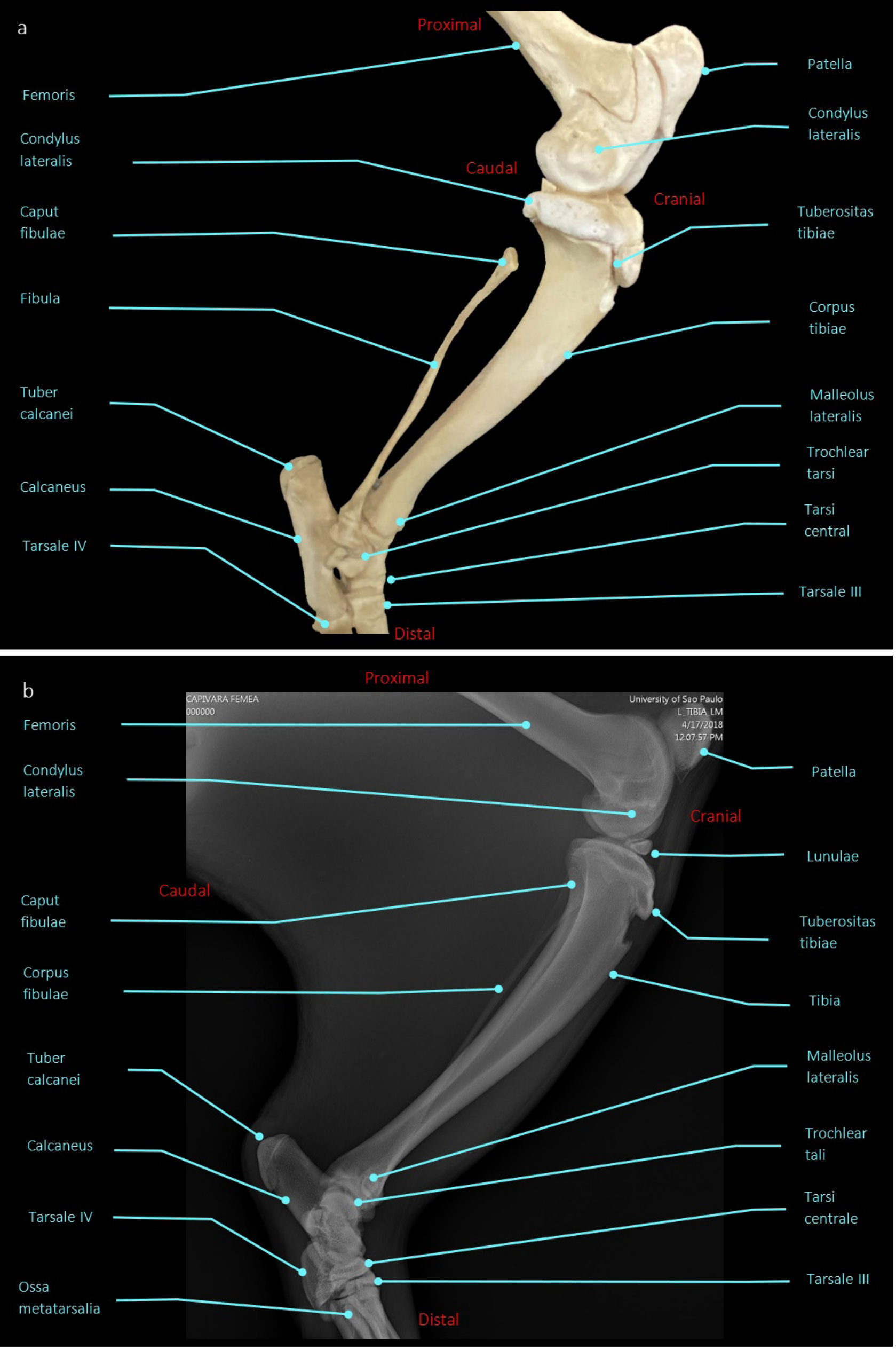

Figure 11 - (a) Lateral view skeleton cruris; (b) Lateral radiographic projection of skeleton cruris. 


\section{Ossa metatarsalia (Figure 12a, b)}

Radiographically, as well as macroscopically, only four ossa metatarsale (I, II, III, IV) were observed, the first metatarsal, being a vestigial bone, and only marginally visible at the dorsoplantar projection. A fifth metatarsal was not observed.

\section{Ossa digitorum pedis (Figure 12a, b)}

The first and fifth digits are also lacking, only digit II, III, and IV with their proximal, medial, and distal phalanges were observed. In the same radiograph, paired ossa sesamoideum metatarsale are present at each metatarsophalangeal articulation, and on the plantar aspect, between the medial and distal articulation, a single sesamoid bone is observed.

\section{Skeleton pedis}

\section{Medical procedure training}

Endotracheal Tube Placement (Figure 13)

The capybara trachea was observed as a narrow tube made up of incomplete c-shaped cartilaginous rings, passing deep embedded through the neck portion, surrounded by large adipose tissue and several anterior neck muscles, connecting the larynx to the lungs. Intubating is done by passing the endotracheal tube through the very narrow opening in the palatum molle (velum palatinum), close to the base of the lingua, called the palatal ostium, a structure present in Caviidae (Rosenthal et al., 2008), to reach the epiglottis and trachea.

\section{Medical procedure training - intubation - urethral catheterization}

Urethral Catheterization for Pharmacologic Semen Collection/Urethrography (Figure 13b)

After extruding the penis, urethral catheterization was performed, followed by contract injection. The contrast solution showed the path of the catheter, entering the glans penis, passing through the urethra, toward the prostate, before entering the urinary vesicle.

\section{Discussion}

The use of digital radiography significantly facilitated the identification and topography of bone structures, especially structures that are often no longer available in macerated bone specimens.

Morphological characteristics are related to cursorial adaptation and foraging patterns, meaning, the way animals move in their environment (Stein \& Casinos, 1997). Comparing the overall bone morphology of the Hydrochoerus hydrochaeris with other rodent species, certain indications for an adaptation to aquatic life can be made.

One of the greatest discrepancies found in the literature is reported body weight, which we believe is due to the use of the same information of original reports, as well as the significant differences in weight between capybaras in their natural biomes versus synanthropic animals. An average reported body weight for adult capybara's in the wild is between 40-50 kg (Moreira et al., 2013), whereas some members in agricultural and urban areas were reported with up to $105 \mathrm{~kg}$ (Rosenfield et al., 2020), < 100\% weight variation. Thus, we suggest considering a differentiation between $H$. hydrochaeris silvestris to $H$. hydrochaeris synanthrope, due to the fact of substantial weight variation, in some case > $100 \%$. This inevitably has an impact on the development of body mass and correlated bone structure while influencing habitual adaptation, and consequently, changing how these animals are being handled, besides clinical implications, for example, anesthetic dosage calculations.

We were able to identify 28 bones in the cranium. However, the literature describes as many as 34 bones, including ossicula auditus (Bode et al., 2016b; Pereira, 2019). The os interparietal was not observed macroscopically, a finding supported by Pereira (2019), as well as os vomer, (perhaps fractures during the maceration process). However, in the radiograph (Figure $3 \mathrm{~b}$ ), the os vomer could be identified, which is also per the observations by Pereira et al. (2020). Further osteological characteristics, and perhaps the most evident to aquatic life, is seen in the shape of the cranium, allowing animals to maintain eyes, ears, and nose above water level. The capybara's perhaps most distinctive anatomical features are the large rootless and continuously growing incisors, with one upper and one lower pair, separated by a large diastema from the cheek teeth. As herbivores, these incisors serve to cut plants close to the roots, and are formidable weapons, potentially provoking deep lacerations. No dente canini were present.

The anticlinal vertebra of the caudal thoracic vertebral column is where the vertebral anatomic feature distinctively changes: the spinous process becomes perpendicular to the body and the preceding vertebrae incline caudally, serving as a point of reference in diagnostic imaging. However, this differs between species, for example (T16 in the horse, T11 in the big or medium dogs, T10 in small dogs, and T11 to T13 in the ox) (Slijper, 1946). We identified T12 as the vertebrae anticlinalis (Figure 1, and Figure 5a,b).

The os sacrum was found with 4 fused vertebrae, caudally reducing in size. The first vertebrae sacrales (S1) is also the largest, becoming significantly smaller in the 

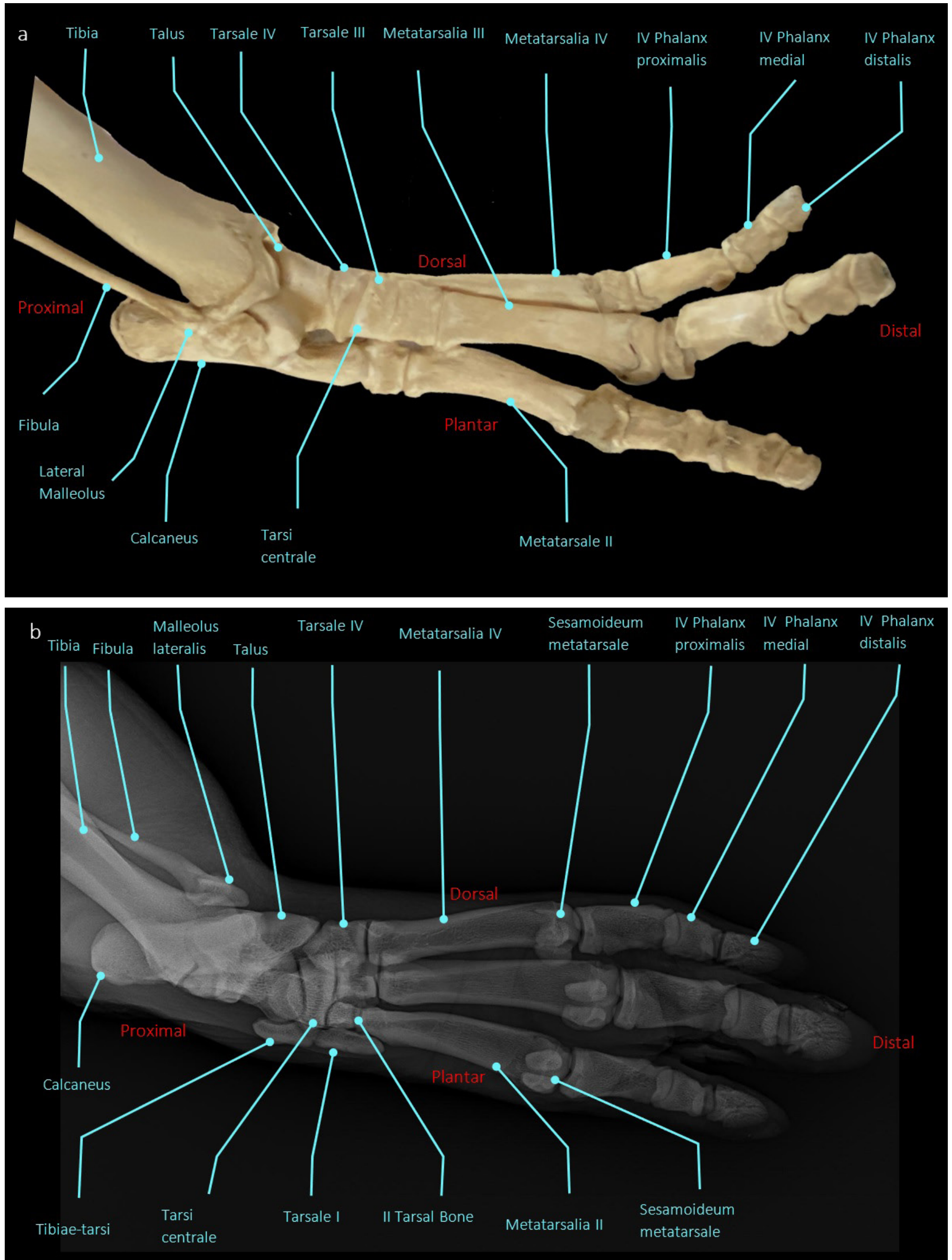

Figure 12 - (a) Lateral/oblique view of skeleton pedis; (b) Latero/oblique radiographic skeleton pedis 

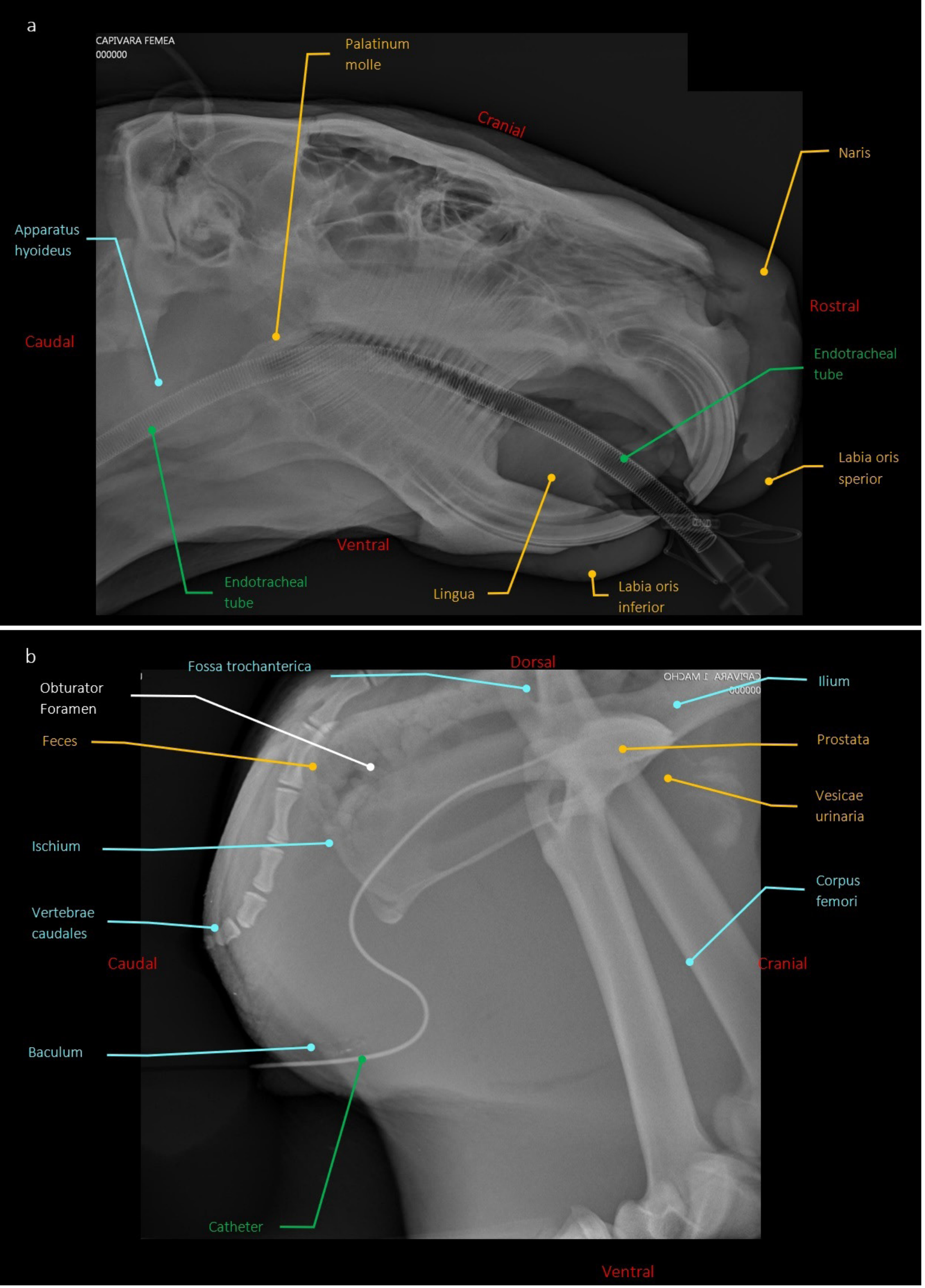

Figure 13 - (a) Laterolateral radiographic view of intubated male capybara. Outliner - Yellow: Soft tissues; Green: Metal-reinforced endotracheal tube; Blue: Cartilaginous structures; Red labels: Directional indicator; (b) Lateral view of an adult male capybara pelvic region; (b) Laterolateral radiographic view of the pelvic region with urethral catheterization. 
caudal direction, until the smallest, (S4). This is a different finding than reported by Kihara (2017), describing the fused vertebrae of the same size. Regarding the processus spinosus, we observed the same reported size-reduction toward the caudal direction.

The vestigial tail, with 8 vertebrae coccygeae, capybaras are considered tail-less caviids (Russo, 2015), compared to most of the 1,500+ Rodentia species, with some having over 30 vertebrae caudales.

Literature review of the cingulum membri thoracici, part of the skeleton appendicular, another adopted characteristic found is the clavicula, responsible for the extension of the limb motion. Some rodent species show a reduced or absent clavicle, believed to allow the scapula to slide further across the ribcage. In Caviomorpha, the clavicle is described as rudimental and, in fact, within Rodentia, the smallest clavicula is found in capybaras. This, in our belief, suggests its specialized adaptation to locomotion on land and water, hence, running-swimming-diving similar to the description of the cursorial (digger)-swimming classified Agouti paca (Elissamburu \& De Santis, 2011). Although the clavicula in H. hydrochaeris could not be observed in this work, microscopically, possibly identifiable radiographically (Figure 12b), its presence is reported in works of Bode et al., (2016a) and Rocha-Barbosa et al. (2002).

Examining the skeleton brachii, we noticed at the ulna a rather large olecranon, with a protruding tuber olecrani.

All Caviidae have four digits on their os manus (forefeet), the fifth is vestigial, and three on their os pes (hindfeet) (Delaney et al., 2018).

Macroscopic observation of the sesamoid bones and lunulae could not be performed, as the specimens were not recovered during the maceration process. During the radiographic examination, however, several well-defined ossa sesamoidea and ossicle lunulae were evident. This was confirmed by reports through available literature (Bode et al., 2016a; Kihara, 2017), similar to Cuniculus paca and Cavia porcellus (Araújo et al., 2012), located normally craniomedial and craniolateral of the femur's condylus medialis and condylus lateralis.

In some literature, the development of the general bone structures of $H$. hydrochaeris, more specifically the member of the cingulum membri thoracici, are related to evolutionary history, particular habits, and functional specialization. Furthermore, comparing the humerus between various members of the Caviomorph rodents, classified the capybara as having a cursorial (running) habit. Although we agree with the morphological description of the humerus, as robust humeri, with well-developed tuberosities and a proximally located deltoid, as mentioned before, we do not concur with the habitual classification of a cursorial form. Moreover, referring to Cuniculus's humeri shape to a wider functional spectrum, including running, swimming, and digging (Morgan \& Álvarez, 2013), is a classification we find equally adequate for $H$. hydrochaeris. We also observed the tuberculum majus to be aligned with the caput humeri, different than described by Bode et al. (2016a) and Kihara (2017). One of the more distinctive features of the humeri was the fossa trochanterica, in our specimen even continuous in cranial-caudal direction, rather than just a deep depression, as with other rodents. Although a deep fossa in H. hydrochaeris is reported, no mention of it in any of the available literature is made, about a continuous opening (Araújo et al., 2012; Bode et al., 2016a, 2016b; Brombini et al., 2018; Moreira et al., 2013; Schimming et al., 2015). Although not unique to $H$. hydrochaeris, the identification of the fossa might aid in species identification. At the humeri, we did not observe the tuberculum majus protruding pass the caput humeri, contrary to reports by Kihara (2017). However, this might be due to age and/or individual variations.

At the skeleton femoris, while mentioned in several works (Araújo et al., 2012; Kihara, 2017; Silveira, 2019), ossa sesamoidea m. gastrocnemii, and sesamoideum m. poplitei were not observed macroscopically, and not captured in the radiographic lateromedial projection.

Regarding skeleton cruris, Araújo et al. (2012) described the attachment of the distal fibula to the tibia by a soft tissue as a particularity of $H$. hydrochaeris, appearing to be part of the tibia. This was an observation we could confirm, macroscopically and radiographically.

Reviewing the literature about ossa metatarsalia, and compared to our findings, we noticed contradicting reports about the number of ossa. Examining the skeleton pedis, we observed four ossa metatarsalia, different than the reported five (Silveira, 2019; Araújo et al., 2012). Furthermore, Brombini et al. (2018) allegedly did not describe the os metatarsale $\mathrm{V}$, which stands in disagreement with our interpretation, explaining that: "the $\mathrm{V}$ metatarsal bone was better identified macroscopically". We consider that the os metatarsalia $\mathrm{V}$ was not evident during our macroscopic exam because of not being available as a specimen, and radiologically, because of the projections taken. Therefore, we cannot rule out its existence.

Regarding the partes genitales masculinae externae, the penis, if not erected, remains in intraabdominal position (Moreira et al., 2013), and needs to be extruded to identify gender in younger males, or for other clinical procedures, 
such as semen collection. The small os penis, baculum, or penile bone, common in rodent species (Upham \& Patterson, 2015), is located dorsally along the glans penis, similar to descriptions in Cavia porcellus (Stan, 2015), not distinctively visible in the radiographs. As the capybara penis is made up of the corpora spongiosa, it does not provide sufficient rigidity for intravaginal penetration for vaginal penetration, the baculum is thought to be structural support, as described by Paula \& Walker (2013), and in comparison, to other species, possessing a shorter baculum $(3-4 \mathrm{~cm}$ in length), the location indicated in the radiograph.

As for medical procedure training, performing orotracheal intubation in capybaras is inherently difficult and several attempts were necessary to finally place the endotube correctly within the trachea. Using a laryngoscope with a straight and extended lamina assisted in depressing the large tongue, reaching the deep located and smalldiameter palatal ostium, glottis, and trachea. Using a metal-reinforced endotube aided in maintaining the tube ridged. Special care must be given not to traumatize these highly vascular structures. As the trachea is deeply embedded in the neck portion, under layers of adipose tissue and muscles, palpation is difficult, not allowing to assist in tube placement or endoscopic procedures. Several works of literature recommend the use of 6.0 endotube and an endoscope to aid in the visualization of the epiglottis during the intubation (West et al., 2013). With the animal in dorsal recumbency, curving the endotracheal tube toward the animal's ventral side will help to access the trachea, as the esophagus is located dorsally. The lateral radiograph provides a well-defined outline with fine radiopaque lines around the metal-reinforced tube.

Collecting semen through catheterization, as described in detail at the works by Araujo et al. (2020) and Rosenfield et al.
(2020), has become a method of interest, and demanded further training.

\section{Conclusion}

The digital radiography allowed us to observe bone structures and topography in great detail, aiding in the overall osteological study of Hydrochoerus hydrochaeris. The results in this research might call for further studies on the evolutionary dynamics of the skeleton development between synanthropic and non-synanthropic capybaras.

\section{Conflict of Interest Statement}

The authors declare no conflict of interests in the current manuscript.

\section{Ethics Statement}

This study, part of a larger project on Capybara Population Control, was approved by the Animal Use and Ethics Committee Faculty of Veterinary Medicine and Animals Science, University of Sao Paulo (protocol number 9553260816).

\section{Acknowledgments}

Several people and institutional departments of the University of Sao Paulo aided during the preparation of this work. The authors would like to extend their appreciation to the following: Prof. Dr. André Luis do Valle De Zoppa, Department of Veterinary Clinic and Surgery, Faculty of Veterinary Medicine and Animal Science, University of Sao Paulo, Brazil and Prof. Dr. Stefano Carlo Filippo Hagen, Department of Veterinary Clinic and Surgery, Faculty of Veterinary Medicine and Animal Science, University of Sao Paulo, Brazil.

\section{References}

Abreu Bovo AA. Capybaras (Hydrochoerus hydrochaeris) in anthropogenic environments: challenges and conflicts. In: Gheler-Costa C, Lyra-Jorge MC, Verdade LM, editors. Biodiversity in agricultural landscapes of southeastern Brazil. Warsaw: De Gruyer; 2016. p. 179-89. http://dx.doi. org/10.1515/9783110480849-013.

Araújo FAP, Sesoko NF, Rahal SC, Teixeira CR, Müller TR, Machado MRF. Bone morphology of the hind limbs in two caviomorph rodents. Anat Histol Embryol. 2012;42(2):11423. http://dx.doi.org/10.1111/j.1439-0264.2012.01172.x. PMid:22731111.
Araujo GR, Paula TAR, Deco-Souza T, Morato RG, Bergo LCF, Silva LC, Jorge-Neto PN, Sampaio BFB. Pharmacological semen collection in cougars (Puma concolor: Mammalia: Carnivora: Felidae). Arq Bras Med Vet Zootec. 2020;72(2):43742. http://dx.doi.org/10.1590/1678-4162-11030.

Bode FF, Cao JA, Resoagli JM, Fernández JA, Llano Laiseca E. Descripción anatómica del esqueleto apendicular del carpincho (Hydrochoerus hydrochaeris). Rev Vet. 2016a;25(1):21. http://dx.doi.org/10.30972/vet.251544.

Bode FF, Fernández JA, Cao JA, Resoagli JM. Descripción del esqueleto axial del carpincho (Hydrochoerus hydrochaeris). 
Rev Vet. 2016b;24(1):44. http://dx.doi.org/10.30972/ vet.2411149.

Brombini GC, Rahal SC, Schimming BC, Santos IFC, Tsunemi MH, Mamprim MJ, Alves LS, Filadelpho AL, Teixeira CR. Radiological and osteological study of the pelvic limbs in free-ranging capybaras (Hydrochoerus hydrochaeris). Anat Histol Embryol. 2018;47(3):239-49. http://dx.doi. org/10.1111/ahe.12349. PMid:29492995.

Delaney MA, Treuting PM, Rothenburger JL. Rodentia. In: Terio KA, McAloose D, St Leger J, editors. Pathology of wildlife and zoo animals. London: Academic Press; 2018. p. 499-515. http://dx.doi.org/10.1016/B978-0-12805306-5.00020-1.

Elissamburu A, de Santis L. Forelimb proportions and fossorial adaptations in the scratch-digging rodent Ctenomys (Caviomorpha). J Mammal. 2011;92(3):683-9. http://dx.doi. org/10.1644/09-MAMM-A-113.1.

Girotto CH. Avaliação da máscara laríngea como alternativa a sonda endotraqueal para manutenção da anestesia inalatória sob ventilação espontânea em capivaras (Hydrochoerus hydrochaerus) [thesis]. Botucatu: Faculdade de Medicina, Universidade Estadual Paulista "Júlio de Mesquita Filho"; 2018.

Herrera EA. Capybara social behavior and use of space: patterns and processes. In: Moreira JR, editor. Capybara: biology, use and conservation of an exceptional neotropical species. New York: Springer; 2013. p. 195-207. http://dx.doi. org/10.1007/978-1-4614-4000-0_11.

Hirota IN, Alves LS, Gandolfi MG, Félix M, Ranzani JJT, Brandão CVS. Tomographic and anatomical study of the orbit and nasolacrimal duct in capybaras (Hydrochoerus hydrochaeris: Linnaeus, 1766). Anat Histol Embryol. 2018;47(4):298-305. http://dx.doi.org/10.1111/ahe.12352. PMid:29532494.

International Committee on Veterinary Gross Anatomical Nomenclature - ICVGAN. Nomina Anatomica Veterinaria 6th ed. Germany: Editorial Committee Hanover; 2017.

Kihara MT. Descrição anatomorradiográfica do esqueleto axial, do membro torácico e dos dentes da capivara (Hydrochoerus hydrochaeris) [thesis]. Jaboticabal: Universidade Estadual Paulista "Júlio de Mesquita Filho"; 2017.

Luz HR, Costa FB, Benatti HR, Ramos VN, Serpa MCA, Martins TF, Acosta ICL, Ramirez DG, Muñoz-Leal S,
Ramirez-Hernandez A, Binder LC, Carvalho MP, Rocha V, Dias TC, Simeoni CL, Brites-Neto J, Brasil J, Nievas AM, Monticelli PF, Moro MEG, Lopes B, Aguiar DM, Pacheco RC, Souza CE, Piovezan U, Juliano R, Ferraz KMPMB, Szabó MPJ, Labruna MB. Epidemiology of capybaraassociated Brazilian spotted fever. PLoS Negl Trop Dis. 2019;13(9):e0007734. http://dx.doi.org/10.1371/journal. pntd.0007734. PMid:31490924.

Moreira JR, Ferraz KMPMB, Herrera EA, MacDonald DW, editors. Capybara. New York: Springer New York; 2013. http://dx.doi.org/10.1007/978-1-4614-4000-0.

Morgan CC, Álvarez A. The humerus of South American caviomorph rodents: shape, function, and size in a phylogenetic context: shape variation of humerus of caviomorph rodents. J Zool. 2013;290(2):107-16. http:// dx.doi.org/10.1111/jzo.12017.

Ojasti J. Estudio biológico del chigüire o capibara. Caracas, Venezuela: Fondo Nacional de Investigaciones Agropecuarias; 1973. $292 \mathrm{p}$.

Passos Nunes FB, da Silva SC, Cieto AD, Labruna MB. The dynamics of ticks and capybaras in a residential park area in Southeastern Brazil: implications for the risk of Rickettsia rickettsii infection. Vector Borne Zoonotic Dis. 2019;19(10):711-6. http://dx.doi.org/10.1089/vbz.2019.2479. PMid:31135286.

Paula TAR, Walker N. Reproductive morphology and physiology of the male capybara. In: Moreira JR, editor. Capybara: biology, use and conservation of an exceptional neotropical species. New York: Springer; 2013. p. 107-29. http://dx.doi.org/10.1007/978-1-4614-4000-0_6.

Pereira FMAM, Bete SBS, Inamassu LR, Mamprim MJ, Schimming BC. Anatomy of the skull in the capybara (Hydrochoerus hydrochaeris) using radiography and 3D computed tomography. Anat Histol Embryol. 2020;49(3):31724. http://dx.doi.org/10.1111/ahe.12531. PMid:31981432.

Pereira FMAM. Estudo do crânio de capivaras (Hydrochoerus hydrochaeris): craniometria, radiografia e tomografia computadorizada 3D [thesis]. Botucatu: Faculdade de Medicina Veterinária e Zootecnia, Universidade Estadual Paulista "Júlio de Mesquita Filho"; 2019.

Rocha-Barbosa O, Youlatos D, Gasc J-R, Renous S. The scapulaer region of some cursorial Cavioidea (Rodentia: mammalia). Mammalia. 2002;66(3). http://dx.doi.org/10.1515/ mamm.2002.66.3.413. 
Rosenfield D, Ferraro M, Igayara C, Cortopassi SRG, Pizzutto CS. Chemical immobilization of free-living capybaras (Hydrochoerus hydrochaeris) using ketaminedexmedetomidine combination and a remote drug delivery system. Braz. J. Vet. Med. 2020;42(1):e107220. http://dx.doi. org/10.29374/2527-2179.bjvm107220.

Rosenfield DA, Nichi M, Losano JDA, Kawai G, Leite RF, Acosta AJ, Baquero OS, Schilbach Pizzutto C. Field-testing a single-dose immunocontraceptive in free-ranging male capybara (Hydrochoerus hydrochaeris): evaluation of effects on reproductive physiology, secondary sexual characteristics, and agonistic behavior. Anim Reprod Sci. 2019a;209:106148. http://dx.doi.org/10.1016/j.anireprosci.2019.106148. PMid:31514916.

Rosenfield DA, Pizzutto CS. Positive-reinforcement strategies to reduce capture-stress in Capybaras. Acta Sci Biol Sci. 2019;41:e45819. http://dx.doi.org/10.4025/actascibiolsci. v41i1.45819.

Rosenfield DA, Polo G, Pizzutto CS. Brazilian spotted fever prevention through a nonlethal capybara population control strategy. Rev Soc Bras Med Trop. 2019b;52:e20190156. http:// dx.doi.org/10.1590/0037-8682-0156-2019. PMid:31596349.

Rosenthal K, Forbes N, Frye F, Lewbart G. Rapid review of exotic animal medicine and husbandry: pet mammals, birds, reptiles, amphibians and fish. 1st ed. FL: CRC Press; 2008.

Russo GA. Postsacral vertebral morphology in relation to tail length among primates and other mammals. Anat Rec. 2015;298(2):354-75. http://dx.doi.org/10.1002/ar.23004. PMid:25132483.

Schimming BC, Rahal SC, Shigue DA, Linardi JL, Vulcano LC, Teixeira CR. Osteology and radiographic anatomy of the hind limbs in Marshdeer (Blastocerus dichotomus). Pesq Vet Bras. 2015;35(12):997-1001. http://dx.doi.org/10.1590/ S0100-736X2015001200009.

Silva E. Estudo anatômico para aplicação clinico-cirúrgica do aparelho locomotor de capivaras (Hydrochoerus hydrochaeris) [thesis]. São Paulo: Universidade de São Paulo; 2019.
Silveira, EED. Estudo anatômico para aplicação clinicocirúrgica do aparelho locomotor de capivaras (Hydrochoerus hydrochaeris) [thesis]. São Paulo: Faculdade de Medicina Veterinária e Zootecnia, Universidade de São Paulo; 2019.

Slijper EJ. Comparative biologic-anatomical investigations on the vertebral column and spinal musculature of mammals. Amsterdam: North-Holland Publishing Company; 1946. $158 \mathrm{p}$.

Stan FG. Anatomical particularities of male reproductive system of guinea pigs (Cavia porcellus). Bull Univ Agric Sci Vet Med Cluj-Napoca Vet Med. 2015;72(2):288-95. http:// dx.doi.org/10.15835/buasvmcn-vm:11410.

Stein BR, Casinos A. What is a cursorial mammal? J Zool. 1997;242(1):185-92. http://dx.doi.org/10.1111/j.1469-7998.1997. tb02939.x.

Upham N, Patterson DB. Evolution of the caviomorph rodents: a complete phylogeny and timetree of living genera. In: Vassallo AI, Antenucci D, editors. Biology of caviomorph rodents: diversity and evolution. Buenos Aires: SAREM; 2015. 58 p.

West G, Heard DJ, Caulkett N. Zoo animal, and wildlife immobilization and anesthesia. Ames: John Wiley \& Sons; 2013. $1360 \mathrm{p}$.

Yanai PR, Cortopassi S. Salpingectomy, and deferentectomy in capybara (Hydrochoerus hydrochaeris, L. 1766): experimental and comparative study between laparoscopic and open surgical approaches [Internet]. 2020 [cited 2020 Aug 15]. Available from: https://www.researchgate.net/ project/Salpingectomy-and-deferentectomy-in-capybaraHydrochoerus-hydrochaeris-L-1766-experimental-andcomparative-study-between-laparoscopic-and-opensurgical-approaches.

Financial Support: This project, in part, was funded by the Sao Paulo Research Foundation (FAPESP), process number: 2016/12549-5. 